\title{
Gondwana-derived microcontinents — the constituents of the Variscan and Alpine collisional orogens
}

\author{
Jürgen F. von Raumer ${ }^{\mathrm{a}, *}$, Gérard M. Stampfli ${ }^{\mathrm{b}}$, François Bussy ${ }^{\mathrm{c}}$ \\ ${ }^{a}$ Department of Sciences Géologiques, Université de Fribourg, CH-1700 Fribourg, Switzerland \\ ${ }^{\mathrm{b}}$ Institut de Géologie et Paléontologie, Université de Lausanne, UNIL BFSH2 CH-1015 Lausanne, Switzerland \\ ${ }^{\mathrm{c}}$ Institut de Minéralogie et géochimie, Université de Lausanne, UNIL BFSH2 CH-1015 Lausanne, Switzerland
}

Received 27 January 2002; accepted 21 July 2002

\begin{abstract}
The European Variscan and Alpine mountain chains are collisional orogens, and are built up of pre-Variscan "building blocks" which, in most cases, originated at the Gondwana margin. Such pre-Variscan elements were part of a preOrdovician archipelago-like continental ribbon in the former eastern prolongation of Avalonia, and their present-day distribution resulted from juxtaposition through Variscan and/or Alpine tectonic evolution. The well-known nomenclatures applied to these mountain chains are the mirror of Variscan resp. Alpine organization. It is the aim of this paper to present a terminology taking into account their pre-Variscan evolution at the Gondwana margin. They may contain relics of volcanic islands with pieces of Cadomian crust, relics of volcanic arc settings, and accretionary wedges, which were separated from Gondwana by initial stages of Rheic ocean opening. After a short-lived Ordovician orogenic event and amalgamation of these elements at the Gondwanan margin, the still continuing Gondwana-directed subduction triggered the formation of Ordovician Al-rich granitoids and the latest Ordovician opening of Palaeo-Tethys. An example from the Alps (External Massifs) illustrates the gradual reworking of Gondwana-derived, pre-Variscan elements during the Variscan and Alpine/ Tertiary orogenic cycles.
\end{abstract}

Keywords: Gondwana-derived terranes; Plate-tectonic terminology; Polymetamorphic basement relics; Collisional orogens; Alpine; Variscan

\section{Introduction}

Careful reconstructions of the Alpine collisional belt are a sound base for comparison of pre-Mesozoic basement areas in the Alps (Frey et al., 1999; Pfiffner et al., 1996; Stampfli et al., 2001a). Alpine

\footnotetext{
* Corresponding author.

E-mail addresses: Juergen.vonRaumer@unifr.ch (J.F. von Raumer), gerard.stampfli@igp.unil.ch (G.M. Stampfli), Francois.Bussy@img.unil.ch (F. Bussy).
}

cross-sections (e.g. Escher et al., 1996; Steck et al., 2001) reveal the complex imbrication of pre-Mesozoic basement blocks juxtaposed by large-scale nappe and strike-slip tectonics. The gradual incorporation of basement units into the nappe structures depends largely on the rheology of the involved rocks resp. minerals, a historical observation made for the Alpine cross-section by Voll (1976). Again, reconstructions of the Variscan orogenic belt (Franke et al., 2000; Matte, 1986; Oncken, 1997) illustrate its complex tectonic evolution and juxtaposition of 
pre-Variscan elements. Deformation similar to the Alpine imbrication of pre-Mesozoic basement had already affected the Pre-Variscan domains before and during the Late Variscan orogenic phase resulting in superposed structures (e.g. Hatcher, 1983). It is the aim of this paper to introduce a terminology characterizing the former peri-Gondwanan plate-tectonic evolution of pre-Variscan basement units constituting part of the Variscan collisional orogen, and to give examples of the stepwise involvement of such basement elements during the Variscan and/or Alpine orogenesis. For this purpose, we are obliged to review certain data, which were largely discussed by von Raumer et al. (2002) and Stampfli et al. (2002).

\section{Peri-Gondwanan evolution}

Pre-Variscan basement relics are essential components in the Variscan basement areas of Europe (Fig. 1), and most of the basement areas under concern are thought to be located, before the Ordovician, in the former eastern prolongation of future Avalonia (see Ordovician reconstruction modified from Stampfli and Borel, 2002, schematic representation in Fig. 2) and had a comparable evolution until the break-off of Avalonia. This holds also for the Alpine realms (External domain, Penninic domain, and parts of the AustroAlpine domain), sharing this geological evolution since the Proterozoic in the prolongation of Avalonia, whereas the Southern

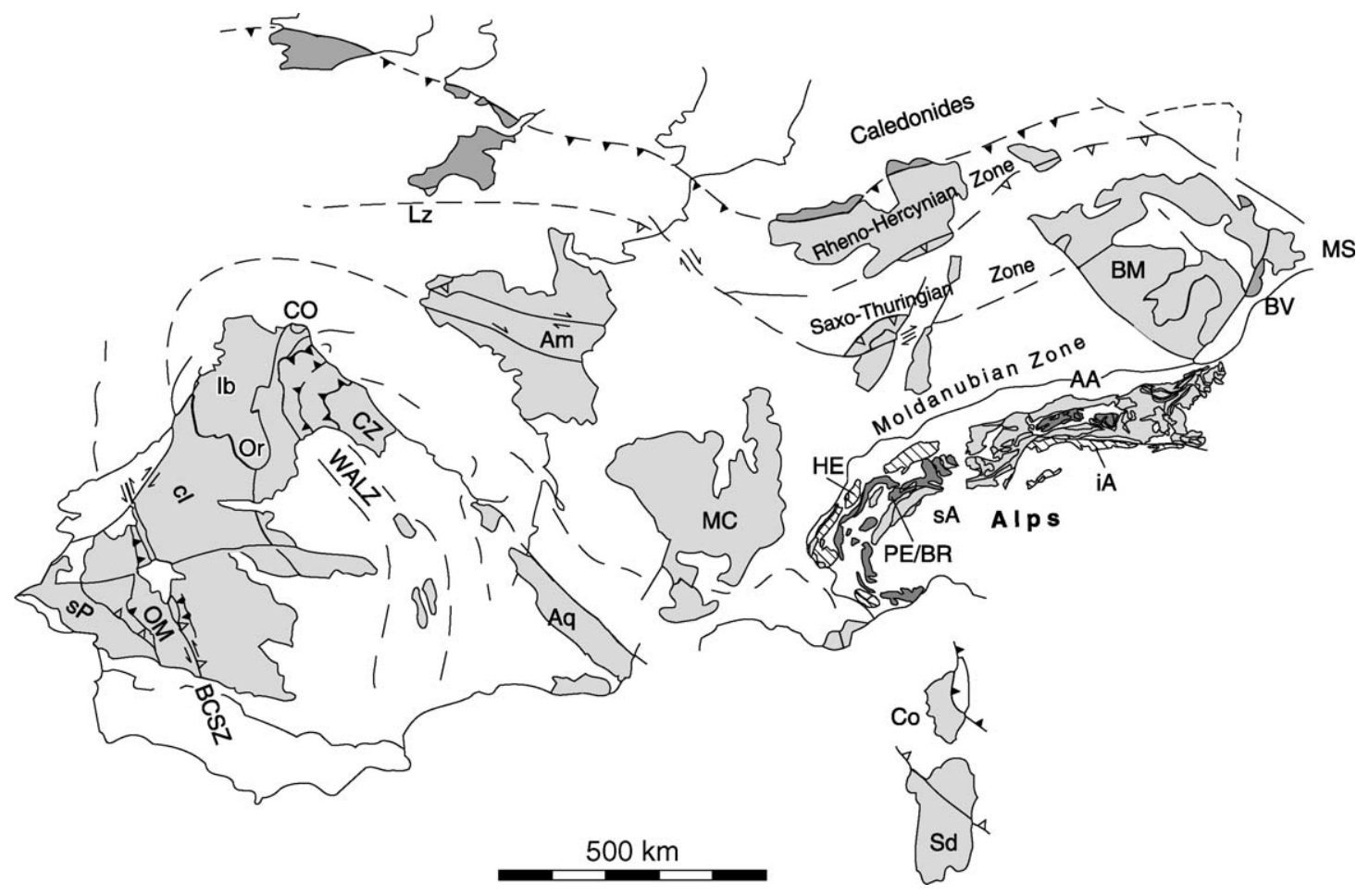

Fig. 1. Geological map of Variscan basement areas in Central Europe based on Franke (1989), Martínez-Catalán (1990), and Ribeiro and Sanderson (1996); nomenclature of the main Variscan units after Kossmat (1927). AA, AustroAlpine (light grey; subdivisions, see Neubauer and Frisch, 1993); Am, Armorican Massif; Aq, Aquitaine; BCSZ, Badajoz-Cordoba Shear Zone; BM, Bohemian Massif; BV, Brunovistulicum; cI, Central Iberian Zone; CO, Cabo Ortegal Complex; CZ, Cantabrian Zone; Co, Corsica; HE, Helvetic Zone (diagonal pattern); iA, Intra-Alpine (diagonal pattern); Ib, Iberia, allochtonous; Lz, Lizard; MC, French Central Massif; MS, Moravo-Silesian; Or, Ordenes ophiolites; OM, Ossa Morena Zone; PE/BR, Penninic/Briançonnais (dark grey); sA, Southalpine; Sd, Sardinia; sP, South Portuguese Zone; WALZ, West Asturias Leon Zone. 


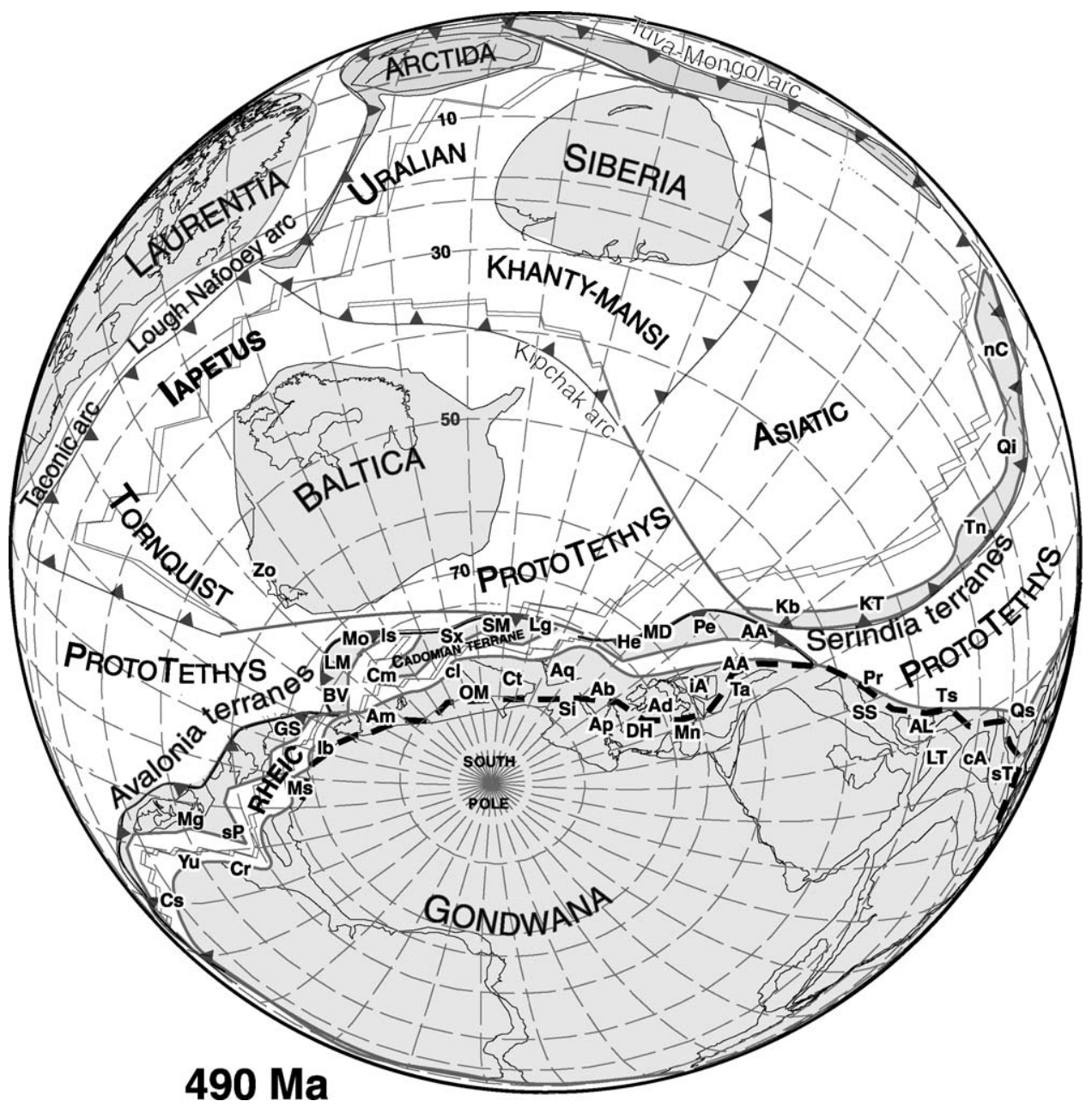

Fig. 2. Early Ordovician plate-tectonic reconstruction (based on Gmap, Torsvik and Smethurst, 1999), centered $60^{\circ} \mathrm{N} / 80^{\circ} \mathrm{E}$, containing informations from Pharaoh (1999), Sengör (1985), Torsvik (1998), Van der Voo (1993), Van Staal et al. (1998); modified from Stampfli and Borel (2002). Dashed line-Future opening of Palaeo-Tethys. Abbreviations: Avalonian Terranes: GS, Gory Sowie; Mg, Meguma; sP, South Portuguese; Avalonian satellites: Is, Istanbul; Mo, Moesia; drift previous to Avalonia (Belka et al., 2002): LM, Lysogory-Malapolska; BV, BrunoVistulikum; Baltica: Zo, Zonguldak; South America: Cs, Chortis; Yu, Yucatan; Cr, Carolina; European Hunic Terranes: AA, AustroAlpine; Ab, Alboran plate; Ad, Adria s.str.; Am, Armorica; cI, central Iberia; Cm, Cadomia; Ct, Cantabria-Asturia; iA, Intra-Alpine terrane; Ib, Iberia, allochthonous; Lg, Ligerian; MD, Moldanubian; Ms, Meseta; OM, Ossa Morena; Pe, Penninic; SM, Serbo-Macedonian; Sx, Saxothuringian; Asiatic Hunic Terranes: Kb, Karaburun; KT, Karakum-Turan; nC, north Caspian; Pr, Pamir; Qi, Qilian; Qs, Qinling south; Tn, Tarim north; Ts, Tarim south; Gondwana (future Cimmerian terrane): Al, Alborz; Ap, Apulia; cA, central Afganistan; DH, DinaridesHellenides; Ki, Kirshehir; LT, Lut-Tabas-Yazd; Mn, Menderes; Si, Sicilia; SS, Sanandaj-Sirjan; sT, Sitia; Ta, Taurus s.l.

Alps were related to the opening of Palaeo-Tethys (von Raumer, 1998).

Referring to von Raumer et al. (2002, with references therein), the occurrences of widespread Neoproterozoic sediments and volcanic arc sequences are the expression of a Neoproterozoic/Early Cambrian active margin setting (e.g. Chen et al., 2000; Crowley et al., 2000; Fernández-Suárez et al., 2000; Finger et al., 2000; Haydoutov, 1989; Schaltegger and Gebauer, 1999; Schaltegger et al., 1997; von Quadt, 1992; Zulauf et al., 1999). Initial rift zones became apparent along the Gondwana margin. Wide areas of detrital sediments and carbonates occupied the Gondwana platform, their maximum depositional age around 
$600 \mathrm{Ma}$ is constrained by the youngest detrital zircons (Schaltegger and Gebauer, 1999). Formation of Cambro-Ordovician oceanic crust is documented from all basement areas (von Raumer et al., 2002), but in contrast to Avalonia, only early stages of the Rheic ocean may have existed in the former eastern continuation of Avalonia (Fig. 2). Differences of evolution through time along the former Gondwana margin may indicate that oceanic crust subducted obliquely and slab roll-back was diachronous. This oblique convergence created different scenarios along the Gondwana margin, where true oceanic crust emplacement appeared in separated pull-apart basins. Laterally, they would have been replaced by isolated continental basins, by activity of plume-like structures (e.g. Bohemian Massif, Floyd et al., 2000), or by volcanites and/or detrital sediment fill. Such strike-slip models had already been proposed by Murphy and Nance (1989); and Murphy et al. (1999) for the Gondwana margin, and have been discussed for the Variscan domain (e.g. Saxothuringian area, Linnemann et al., 1998).

\subsection{Provenance of detrital sediments}

Comparing Nd-isotopic compositions, Liew and Hofmann (1988) gave a medium value of crustal residence ages of 1.4-1.7 Ga for the European Variscan fold belt, and Nance and Murphy (1994, 1996) identified the terrane assemblage "Cadomia" through mainly negative $\varepsilon_{\mathrm{Nd}}$ values and crustal residence ages of 1.9-1.0 Ga from granitoid rocks. Recent data from metasediments of the Mid-German Crystalline Rise yielded concordant $\mathrm{U}-\mathrm{Pb}$ SHRIMP zircon ages, which cluster around $550 \mathrm{Ma}, 1.0$ and 2.0 $\mathrm{Ga}$, and $\mathrm{Nd}$ model ages between 0.9 and $1.3 \mathrm{Ga}$. The combined isotopic data are interpreted to reflect derivation of these sediments from at least three distinct crustal source regions, the Avalonian Cadomian belt, the West African and/or Amazonian cratons and the Grenvillian belt (Zeh et al., 2001). Inherited zircons from protoliths of Ordovician granitoids from Gory Sowie, in the eastern Bohemian Massif, yielded ages of $1.1-1.3,1.6-1.8$, and $2.2-2.6$ Ga with a scatter of $0.86-1.56-\mathrm{Ga} \mathrm{Nd}$ model ages (Kröner and Hegner, 1998). Hegner and Kröner (2000) report mainly $1.7-1.4-\mathrm{Ga} \mathrm{Nd}$ model ages for the areas of the northeastern Bohemian Massif, and $\mathrm{U}-\mathrm{Pb}$ ages of detrital zircons or zircon xenocrysts clustering from 600 to $850 \mathrm{Ma}, 1.0$ to $1.3 \mathrm{Ga}$, and 1.7 to $2.3 \mathrm{Ga}$. Following the model of Fernández-Suárez et al. (2000), they place most of the source areas in an active margin setting along the Amazonian craton, only few areas showing Grenvillian sources. In the Cambrian of the Lysogory Massif, $\mathrm{U}-\mathrm{Pb}$ single-grain dating of detrital zircons reflects sources of $600,1.8$ 2.0 and $>2.5 \mathrm{Ma}$ attributed to Gondwana (ValverdeVaquero et al., 2000). In the southeastern Bohemian massif, the Moravo-Silesian unit, Friedl et al. (2000) obtained from inherited zircons in a Late Neoproterozoic (580 Ma) orthogneiss concordant $\mathrm{U}-\mathrm{Pb}$ zircon SHRIMP ages around 1.2, 1.5 and 1.65-1.8, and 2.3 Ga (Friedl et al., 2002) supporting an affiliation to Avalonia and a relationship with the Grenvillian domain from South America. In the Southern Alps (Lucomagno area), $\mathrm{U} / \mathrm{Pb}$ zircon ages from augengneisses indicate $1.0,2.0-2.1$ and 2.7-2.9-Gainherited source materials, and $\mathrm{U}-\mathrm{Pb}$ zircon ages from paragneisses indicate 1015-Ma source materials (Böhm, 1996), and $T_{\mathrm{DM}} \mathrm{Nd}$ model ages in the orthoand paragneisses range from 1.0 to 1.4 Ga resp. 1.3$1.7 \mathrm{Ga}$. In the AustroAlpine Silvretta basement unit, Cambro-Ordovician orthogneisses have upper $\mathrm{U} / \mathrm{Pb}$ zircon intercepts at $2.9 \mathrm{Ga}$, lower intercepts at 470 $\mathrm{Ma}$, and 1.7-1.2 $\mathrm{Nd}$ model ages (Liebetrau and Nägler, 1994; Poller, 1997). The $1.7 \mathrm{Nd}$ model age was interpreted as a homogeneous mixture of continental sediments (max. $2.3 \mathrm{Ga}$ ) and younger basic components (Poller et al., 1997). Cambrian (520 Ma) metagabbros (with IAB signature) and metatonalites yielded $0.9-1.1-\mathrm{Ga} \mathrm{Sm}-\mathrm{Nd}$-depleted mantle model ages (Schaltegger et al., 1997). U-Pb zircon ages on xenocrysts or detrital zircons from the pre-Alpine basement of the Internal Western Alps yielded Archean and Grenvillian ages (Bertrand et al., 2000). All these data show that the different continental blocks inherited detritus from source areas having undergone older orogenies around 1.0, 1.7 and $2.0 \mathrm{Ga}$.

Considering the age groups discussed above, the different authors agree in the existing relationship between age of zircon xenocrysts, detrital zircons and their source areas in the older gneiss cores of South America and/or the West African craton, and in the Grenville Belt. The question arises on what kind of relationship existed between the continental blocks 
located in the eastern prolongation of Avalonia and Cadomia during the Cambro-Ordovician and the Amazonas resp. the West African regions. Keppie and Dostal (1998) place the Avalon Composite Terrane in a 630-Ma reconstruction adjacent to the Amazon Craton and the Grenville Belt. The different microcontinental blocks composing Avalonia, Cadomia and the Hunic terranes (Fig. 2) underwent the Cadomian/Pan-African orogenic events at the Gondwana margin. Before and during this long lasting orogenic evolution, there has been time enough for recycling material, thus allowing to find xenocrysts and detrital zircons of Archean and Grenville age in the Late Proterozoic to Cambrian detrital sediments recycled in many of the pre-Variscan and Variscan granitoids in Europe. Long distance river transport of sediments has been discussed by Zeh et al. (2001). Many of the interpretations mentioned above and the situation of source areas were based on Hoffman's (1991) Rodinia model. Although we cannot give a different interpretation, we would like to point out that besides the South American or West African areas, other source areas may have existed, when considering the plate-tectonic evolution of blocks occupying the former eastern Gondwanan areas, at present being part of India and of the Himalayas. Additionally, Wingate et al. (2002) propose a Rodinia model, where Grenvillian elements have a very different distribution and, consequently, there may be an additional degree of freedom to place Archean and Grenville age sources along the Gondwana margin. Such major revisions of reconstructions could have considerable consequences for placing Gondwana-derived microcontinents at the Gondwana margin.

\subsection{Evolution of magmatic rocks}

During the Cambro-Ordovician plate-tectonic evolution of the Gondwana-derived microcontinents, magmatic rocks have played an important role. Different emplacement processes, taking place at rift, at active margin or at collisional setting, have been invoked to explain their emplacement. The nearly identical chemical composition of Cambro-Ordovician granitoids in mantle-normalized multi-element variation diagrams supposes recycling of widely distributed, homogeneous detrital sedimentary sources (e.g. Ugidos et al., 1997). Despite this homogeneity, the chemical evolution of the many Cambro-Ordovician granitoids cannot be simply explained in applying a single rifting, active margin or collisional tectonic model. Depending on age and emplacement of granitoids, evolution through time has to take into account all three settings. Although presentation in a plate-tectonic discrimination diagram (Maniar and Piccoli, 1989) cannot be a satisfying solution, a trend of chemical evolution through time becomes apparent (Fig. 3, with localities and references), as granitoids plot more or less into fields, defining a distinct platetectonic setting (Maniar and Piccoli, 1989). Dated Cambrian plagiogranites from different localities (Fig. 3) plot into the field of oceanic granites defined by Maniar and Piccoli (1989), and are related to formation of oceanic crust during the opening of the Rheic ocean. Cambrian to Early Ordovician alkaline granitoids from several localities plot into the field of alkaline granites (Fig. 3) and should represent rifting stages of thickened crust contemporaneous to the opening of the Rheic ocean. Relatively early (Early Ordovician) calc-alkaline metaluminous granites plot into the field of arc-related granites (Maniar and Piccoli, 1989), and were probably related to a nearby Cambro-Ordovician active margin setting. The many, relatively younger $( \pm 450 \mathrm{Ma})$, more or less calcalkaline peraluminous granitoids, plot into the welldefined field of collisional granites and carry the characteristics of a late- to post-orogenic evolution (von Raumer et al., 1999b, 2002).

Intrusion of Cambro-Ordovician granitoid rocks is accompanied, at several places, by Early Palaeozoic metabasic rock series. The Cambrian granite and gabbro intrusions of NW Spain, accompanied by metamorphism, and anatexis (Abati et al., 1999), are in our opinion closely related to the rifting of the Rheic ocean. Equally, time parallels of intrusions of mafic rocks and opening of early stages of the Rheic ocean exist in the French Central Massif (Briand et al., 1995; Pin and Marini, 1993), in the Alpine External Massifs (Ménot, 1987), in the Saxothuringian domain (Kemnitz et al., 2002), and in the Bohemian Massif (Furnes et al., 1994; Stipska et al., 2001). Based on many chemical data from the Bohemian Massif (Floyd et al., 2000), Crowley et al. (2000) apply Storey's (1995) model, interpreting the general Cambrian continental break-up as a consequence of mantle-plume evolution through time. Mantle plumes may 


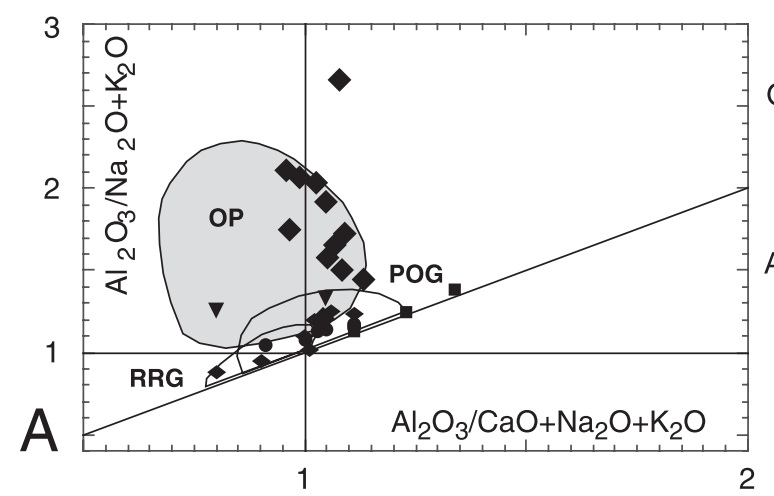

\section{Oceanic Plagiogranites}

- Chamrousse

Silvretta

Alkaline Granites

- Malpica-Tuy

- Mt. Pourri

- Thyon

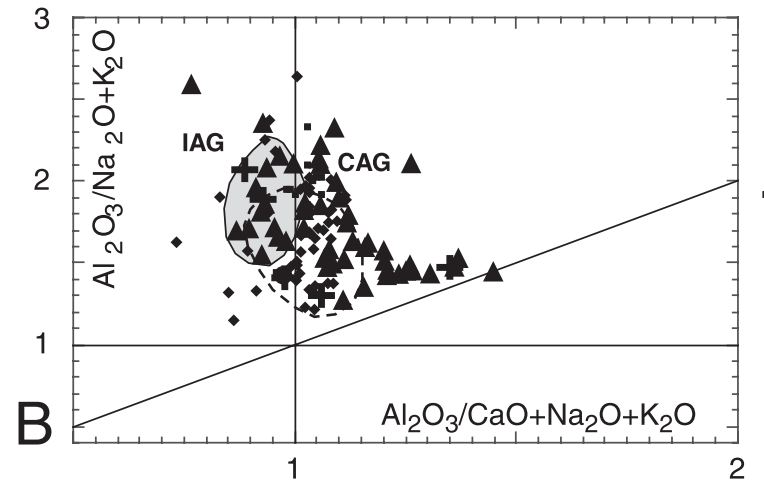

$\Delta$ Ceneri

- Aiguilles Rouges Wirsing

t Bohemian Massif

- Oetztal

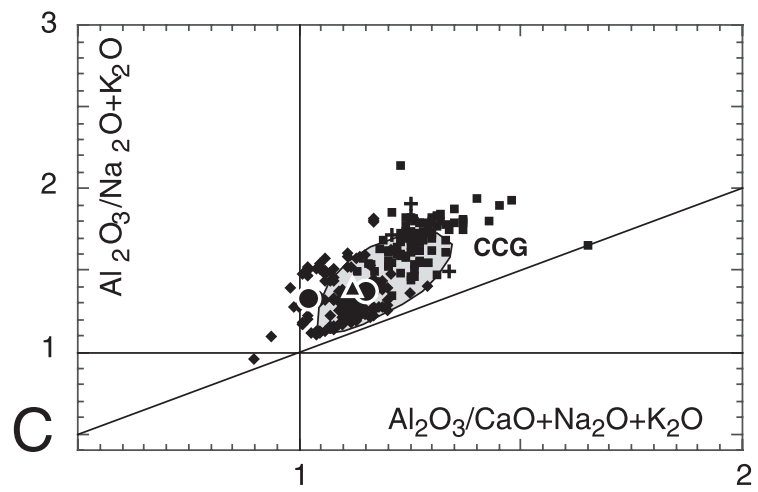

- Aiguilles Rouges

Gotthard

- Silvretta

+ Poland

A Canigou/Pyrenees

Fig. 3. Plate-tectonic discrimination of granites after Maniar and Piccoli (1989)—application to pre-Variscan granitoids in the peri-Gondwanan domain. Definitions and fields after Maniar and Piccoli (1989): OP, oceanic plagiogranites; IAG, island-arc (Calcic to calc-alkaline); CAG, continental arc granites (calc-alkaline); RRG, rift-related granitoids (alcalic); POG, post-orogenic granitoids (alcali-calcic); CCG, continental collision granitoids (calc-alkaline to alkali-calcic). (A) Mainly Cambrian granitoid rocks (Plagiogranites: Chamrousse (Ménot, 1987); Silvretta (Müller et al., 1996); Alcaline granitoids: Malpica-Tuy, Ordovician (Pin et al., 1992); Mt. Pourri (Guillot et al., 1991); Thyon (Bussy et al., 1996). (B) Cambro-Ordovician I-type granitoids: Aiguilles Rouges (Wirsing, 1997); Bohemian Massif (Kröner et al., 2000); Oetztal (Schindlmayr, 1999); Ceneri (Boriani et al., 1981; Pezotta and Pinarelli, 1994); part of the Ceneri-gneisses plot into the field of collisional granites. (C) Ordovician collisional-type granitoids: Gotthard (Sergeev, unpublished data); Aiguilles Rouges (Wirsing, 1997; von Raumer, unpublished data; Pyrenees, Canigou (Barbey et al., 2001); Poland (Kröner and Hegner, 1998).

have played an important role in preparing rifting of the Rheic ocean but, in the strike-slip model presented above, rifting as a consequence of stress applied at the plate boundaries during initial back-arc opening is probably as important for the location of oceanic basins as presence of mantle plumes. 


\subsubsection{Separation from Gondwana}

After the initial stages of Cambrian rifting at the Gondwana margin, the pre-Variscan basement blocks which are to become involved into the future Variscan mountain chain, still underwent several steps of plate-tectonic evolution before their drift towards Laurussia (Stampfli et al., 2002; von Raumer et al., 2002).

When Avalonia and its supposed satellites (e.g. BV, GS, Is, LM, Mo; see Fig. 2) separated from Gondwana, during the Early Ordovician, drifting was hampered in the former easterly situated continental blocks (Cadomia, IntraAlpine Terranes) by the still existing oceanic ridge of Proto-Tethys. The Ordovician collision of the detaching terranes with Gondwana triggered the consumption of the embryonic eastern Rheic ocean and the amalgamation of volcanic arcs and continental ribbons with Gondwana in a rather short-lived orogenic pulse (von Raumer, 1998, with references therein). The cordillera, resulting from mid-ocean ridge subduction during the Ordovician, started to collapse already during the Late Ordovician leading to the opening of the Paleo-Tethys rift, followed by the Late Silurian drift of the composite Hun-superterrane (Stampfli, 2000).

Fig. 4. Schematic representation of drift history of Gondwananderived basement areas from the Silurian to the Carboniferous, with representation of the oceanic domains, modified from Stampfli et al. (2002, with more details therein). $440 \mathrm{Ma}$-Indication of intervening main oceanic plates. Avalonia and its satellites (Malapolska, Lysogory, Brunovistulikum, see Belka et al., 2002) are already amalgamated with Laurussia. Subduction at the Gondwana margin continued in the former more eastern located domains. The dashed line indicates location of the future opening of Palaeo-Tethys. 420 $\mathrm{Ma}$ - An archipelago-like ribbon-continent separated from Gondwana (European Hunic Terranes) during opening of Palaeo-Tethys along the Gondwana margin. Its opening is interpreted as back-arc spreading related to Gondwana-directed subduction of Rheic/ProtoTethys. $380 \mathrm{Ma}$-Early collision of Gondwana-derived European Hunic Terranes with Laurussia-derived terranes. $340 \mathrm{Ma}-$ Major collision and closure of Rhenohercynian domain. Abbreviations: AA, AustroAlpine; Ab, Alboran plate; Ad, Adria s.str. Am, Armorica; Aq, Aquitaine/French Pyrenees; Bk, Bolkardag; Ce, Cetic; Ch, Channel Islands; cI, central Iberia; Ct, CantabriaAsturia; Spanish Pyrenees; DH, Dinarides-Hellenides; He, Helvetic; Ib, Iberia, NW-allochthon; Kb, Karaburun; Lg, Ligerian; MD, Moldanubian; OM, Ossa Morena; Pe, Penninic; sA, South Alpine; SM, Serbo-Mazedonian; sP, South Portugese; Sx, Saxothuringian; Tz, Tizia; Zo, Zonguldak.
Well known from the Alpine basement areas, few relics of this episode, either sedimentation in a backarc situation, or a Late Ordovician/Early Silurian
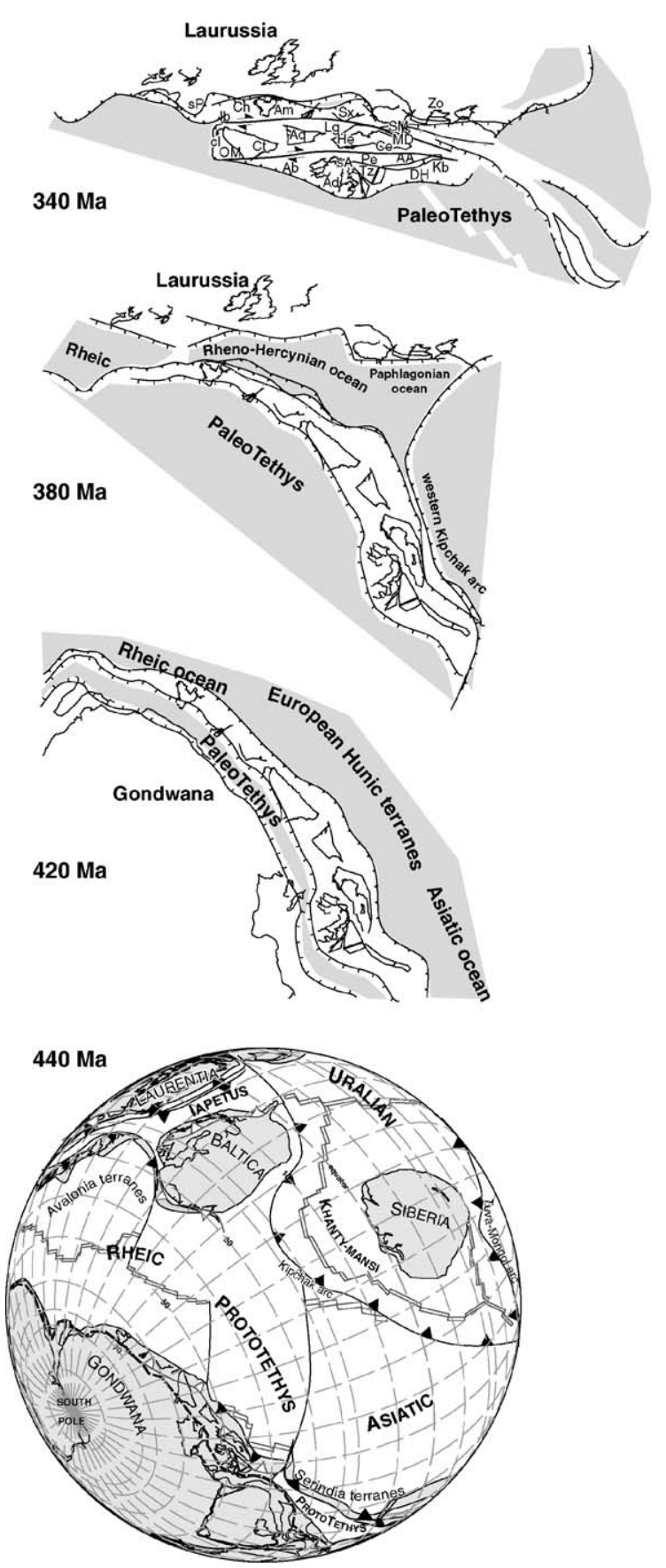
active margin setting are known. If they were not completely consumed during large-scale Variscan subduction, they have still to be identified in many basement areas.

Lack of knowledge about relics of Palaeo-Tethys induced differences when appreciating Variscan tectonic events at the Laurussia border. In contrast to existing reconstructions of the Variscan plate-tectonic evolution (Franke et al., 2000; Matte, 1986), Stampfli et al. (2002) include a Devonian collision between continental ribbons derived from Laurussia/Avalonia and Gondwana which subsequently was followed by the Late Carboniferous collision between Gondwana and Laurussia, leading to the complex Late Variscan terrane duplication known from the European part of the orogen (Fig. 4). However, Palaeo-Tethys was not closed in the Mediterranean area before the Late Triassic (Stampfli and Borel, 2002), and the future Alpine area was subject to large-scale Permian extension and volcanism related to final stages of PalaeoTethys subduction (Ziegler et al., 2001).

\section{The External Massifs - an example of polymetamorphic basement in the Alps}

Nearly half of the Alpine domain is underlain by pre-Mesozoic basement (von Raumer and Neubauer, 1993, 1994). The External Crystalline Massifs of the western/central Alps, especially in the Aiguilles Rouges/Mont-Blanc area, record the OrdovicianVariscan-Alpine polyorogenic evolution outlined above. Understanding of superposed geological events was made possible from precise $\mathrm{U}-\mathrm{Pb}$ zircon and monazite dating (Bussy et al., 2000; Bussy and von Raumer, 1994; Bussy et al., 2001). Magmatic ages on zircon of $\sim 450 \mathrm{Ma}$ (Paquette et al., 1989) have been obtained both for eclogitized MORB-like basic rocks and for S- and I-type orthogneisses. They have been interpreted as evidence for a Late Ordovician subduction zone, either in an island-arc, or an active continental margin environment (e.g. Gotthard area, Oberli et al., 1994).

\subsection{The Variscan evolution}

Paragneisses, possibly part of an accretionary prism (Ordovician or Silurian), display a succession of deformation events ascribed to terrane (or microcontinent) accretion, with thrust movements and nappe stacking, leading to continental crust thickening and the development of a Barrovian-type metamorphism (von Raumer et al., 1999a). During Carboniferous times, the continental lithosphere progressively recovered its original thickness in a transcurrent to extensional tectonic regime ascribed to the roll-back effect of the subducting Palaeo-Tethys slab (back-arc extension). Fast uplift (ca. $1 \mathrm{~mm} /$ year) and vigorous erosion are recorded in a Late Carboniferous intra-continental detrital basin (Capuzzo and Bussy, 2000). The whole area experienced a metamorphic evolution, where paragneisses of favourable composition underwent in situ decompression melting at $320 \pm 1 \mathrm{Ma}(\mathrm{U}-\mathrm{Pb}$ monazite dating), and metapelites yielded a monazite age of $327 \pm 2$ Ma.

Contrasting types of early magmatic rocks (331$332 \mathrm{Ma}$, peraluminous monzogranites, $\mathrm{Mg}-\mathrm{K}$-rich monzonites) intruded syntectonically along major dextral strike-slip faults (Bussy et al., 2001). The $\mathrm{Mg}-\mathrm{K}$ rich monzonites host meter-sized comagmatic durbachitic enclaves of mantle origin (Bussy et al., 2001), and belong to a well-known group of $\mathrm{Mg}-\mathrm{K}$ granites of the Variscan belt emplaced between $\sim 340$ and 330 Ma (Debon et al., 1998). Mg-K magmas are thought to result from the partial fusion of a high-K lithospheric mantle (metasomatized during an earlier subduction event) with subsequent contamination by crustal material (Bussy et al., 2001). Local production of S-type anatectic melts would be favoured by heat transfer from the mantle-derived magmas. Several peraluminous magmatic bodies intruded simultaneously at $307 \mathrm{Ma}$, either syntectonically as vertical sheet-like intrusions within major dextral transtensive zones (Vallorcine and Montenvers granites), or as a large mass of mobile migmatites (Fully anatectic granodiorite). Comagmatic gabbros and mafic microgranular enclaves evidence a mantle magmatic input. The large 304 Ma, alkalicalcic, $\mathrm{Fe}-\mathrm{K}$-rich Mont-Blanc granite is the youngest intrusion in the area. Comagmatic mafic rocks occurring as monzodioritic microgranular enclave swarms, stocks and synplutonic dykes, again document a mantle activity.

The Carboniferous granite magmatism in the Mont-Blanc/Aiguilles Rouges area is thus characterized by the systematic association of Al-rich, crustalderived melts, on the one hand, and mantle-derived 
mafic melts with variable amounts of crustal contamination on the other hand. Their emplacement is influenced by lithospheric-scale transcurrent faults (Burg et al., 1994). The minor volumes of anatectic melts produced by in situ decompression melting must be considered separately.

Following the interpretations by Bussy et al. (2001), this bimodal magmatism is interpreted according to the following scenario: (1) deep-seated crustal rocks are heated up through thermal relaxation after crustal thickening due to the Variscan accretion; (2) the thickened lithosphere is re-equilibrating through extension, mantle upwelling and exhumation/erosion; (3) the metasomatized lithospheric mantle is melting, $\mathrm{Mg}-\mathrm{K}$ liquids are produced and emplaced in upper crustal levels through lithospheric-scale faults; (4) hot mid-crustal rock units experience in situ decompression melting while uplifted; (5) as crust is thinning, mantle is upwelling and evolves towards more primitive asthenospheric composition; mantle magmas of increasingly anorogenic affinity are produced and underplate the crust; (6) mafic magmas bring more heat to the already hot lower crustal levels, triggering large-scale dehydration melting of various lithologies; (7) large volumes of magmas are extracted and collected along active crustal-scale faults and move syntectonically to higher levels.

The proposed evolution is explained in a geodynamic context of oblique, anti-clockwise collision of Gondwana with Laurassia in the western, Appalachian side of the latter during Early Carboniferous times (Stampfli and Borel, 2002), inducing large-scale dextral transcurrent movements in the orogenic zone (e.g. Giorgis et al., 1999). At the same time, but on the eastern side, the Palaeo-Tethys oceanic crust was still subducting underneath the accreted margin of Laurassia (i.e. the Variscan belt, e.g. Vavassis et al., 2000). Slab roll-back induced the above-described Late Carboniferous/Permian extension and magmatic activity.

\subsection{The Alpine overprint}

The Alpine evolution on the other hand is quite different. After reaching a thermal equilibrium in the Helvetic-Penninic units in Permo-Triassic times, the European lithosphere suffered again a major rifting phase starting in Late Triassic and ending in Middle Jurassic with the opening of the Alpine Tethys
(Stampfli et al., 1998). The Variscan basement units were then redistributed as elements of the northern and southern passive margins of this narrow ocean. During the closure of the ocean in Cretaceous and Paleogene times, the southern margin became an active margin, however, with hardly any volcanicity (Stampfli, 2001). The northern margin was flexured and buried sometimes to great depth in OligoceneMiocene time and part of it was obducted and thrusted onto the flexural molassic basin to form the external massifs. This scheme is somewhat perturbed by duplication of both margins in Cretaceous times, with lateral displacement of some units in the order of several hundreds of kilometres, bringing one more perturbation to the former distribution of Variscan elements. A striking example of margin duplication is given by the Alpine "Briançonnais" domain, the present-day Penninic basement areas, which is regarded as an exotic terrane belonging to the European northern margin until Late Jurassic (Stampfli, 1993), which then was transported eastward during the drift of Iberia, and appearing on a present-day Alpine cross-section as a duplication of the European continental margin (Stampfli, 2001). In any case, it is difficult to distinguish a Variscan unit belonging to the northern margin from one of the southern margins.

The Variscan basement areas of the External Massifs have undergone, together with their Mesozoic cover, the tectonic and metamorphic evolution of Alpine/Tertiary age (Frey et al., 1999). In the first distribution map of Alpine metamorphic minerals (Niggli, 1960), it became evident that Alpine metamorphism evolves from lowermost greenschist facies in the North to amphibolite facies grade in the South. Consequently, in the southern sections, even Late Variscan granites are transformed to amphibolite facies grade gneisses (e.g. Fibbia granite, Gotthard Pass, garnet-bearing orthogneiss). Comparable granites in the more external part of the Alps exhibit greenschist facies overprint (e.g. Mont-Blanc granite, von Raumer, 1967), where original brown biotite is mostly replaced by a mosaic of new, green coloured biotite with exsolved sphene following the direction of former cleavage. Original K-feldspar is replaced by chessboard-albite and enlarged perthitic albite veins, the latter still following the original crystallographic orientation of the host. Plagioclase is replaced by 
albite, phengitic white mica and epidote, and quartz shows typical low-temperature polygonal recrystallization.

In such an Alpine greenschist facies environment, some pre-Variscan elements can still be recognized. They mostly attained Variscan amphibolite facies grade and incipient anatectic melting, and were intruded by Late Variscan granites. The Late Variscan high-temperature overprint and the contemporaneous large-scale strike-slip triggered juxtaposition of various pre-Variscan elements, and former plate-tectonic relationships were strongly destroyed. Relics of Ordovician granitoids may serve as a typical example of pre-Variscan elements preserved in the pre-Mesozoic/ Variscan basement areas of the Alps. In contrast to the Variscan granitoids, they mostly appear as pre-Variscan orthogneisses. In high-grade Alpine metamorphic regions such as the Penninic domain, their distinction from Variscan-deformed granitoids remains a challenge (Thélin et al., 1993), which can be resolved only through isotopic dating. In contrast, in lower-grade Alpine greenschist facies regions (e.g. the External Massifs), such orthogneisses can be easily distinguished from Late Variscan granites, as they carry the imprint of Variscan anatectic remelting (e.g. Aiguilles Rouges and Mont-Blanc external massifs, von Raumer, 1998). In such cases, all transitions from shear-bands containing newly formed sillimanite to stringers of melt following the foliation produced during strike-slip to a microgranular new granitoid are observed, where former K-feldspars appear as black coloured, preserved relics, and the former foliation as ghost structure. Variscan strike-slip produced large-scale isoclinal folds of orthogneisses (von Raumer, 1984), whose limbs are strongly sheared and develop characteristic microstructures. The Alpine overprint, following the high-grade Variscan events, depends on the temperature attained. In the Mont-Blanc area (von Raumer, 1984), where Alpine metamorphism reached the biotite-grade, the former granitic matrix of the Ordovician orthogneisses has been transformed into strongly flattened white micaalbite-epidote-chlorite-quartz-biotite-schists, and the large K-feldspar phenocrysts have been stretched about $300 \%$, resulting in a structure of angular relics of blackened microcline, separated by fluid inclusionfilled stretching fibres of albite and quartz. In the domain of lowest grade of Alpine metamorphism (e.g. Aiguilles Rouges), such orthogneisses display formation of chlorite-albite, and very early stages of polygonization of quartz (von Raumer, 1984). Alpine brittle deformation appears as a multitude of tiny chlorite-albite filled cracks, arranged in en-echelon sets, indicating conjugate Alpine shear planes.

The difficulty to distinguish between lithologies is even higher when dealing with metasediments with their former gradual transitions, and basic magmatic rocks, older than Ordovician granitoids. Metabasites very quickly loose important characteristics, when transformed to greenschists, and metasediments with their variable composition are not easy to identify, when transformed into migmatites. Despite such difficulties, comparative studies reveal parallels of evolution across the many Variscan basement areas (von Raumer et al., 2002) and, consequently, we propose in the following chapter a terminology taking into account their pre-Variscan origin.

\section{Plate-tectonic terminology and conclusion}

Modern reconstructions for the Early Ordovician (Stampfli and Borel, 2002 , and Fig. 2) see a lateral continuation of Avalonian-type crustal pieces at the Gondwana margin. Avalonia and some of its supposed lateral satellites separated from Gondwana around 480 $\mathrm{Ma}$, accompanied by the opening of the Rheic ocean. Most of the Pre-Variscan relics of the present-day Variscan basement (the constituents of the Hun terrane, Fig. 5) are separated from Gondwana during the

Fig. 5. Plate-tectonic interpretation of basement areas in Central Europe in terms of former plate-tectonic location of pre-Variscan relics at the Gondwana margin. (A) Permian reconstruction modified from Stampfli et al. (2001b); (B) Silurian reconstruction and abbreviations modified from Stampfli and Borel (2002); (C) Silurian cross-section, interrupted line in B. Abbreviations: AA, AustroAlpine; Ab, Alboran plate; Ad, Adria s.str.; Am, Armorica; Aq, Aquitaine/French Pyrenees; Bk, Bolkardag; BV, Brunovistulian; Ch, Channel Islands; cI, central Iberia; Cm, Cadomia s.str.; CO, Cabo Ortegal; Ct, Cantabria-Asturia; Spanish Pyrenees; DH, Dinarides-Hellenides; GS, Gory Sowie; Gi, Giessen-nappe; He, Helvetic; Hz, Harz mountain; iA, Intra-Alpine terrane; Ib, Iberia, NW-allochthon; Kb, Karaburun; Lg, Ligerian; Lz, Lizard; MD, Moldanubian; Ms, Meseta, Morocco; MS, Moravo-Silesian; OM, Ossa Morena; Or, Ordenes ophiolites; Pe, Penninic; Pe/Br Penninic/Briançonnais; sA, South Alpine; SM, Serbo-Mazedonian; sP, South Portugese; Sx, Saxothuringian. 


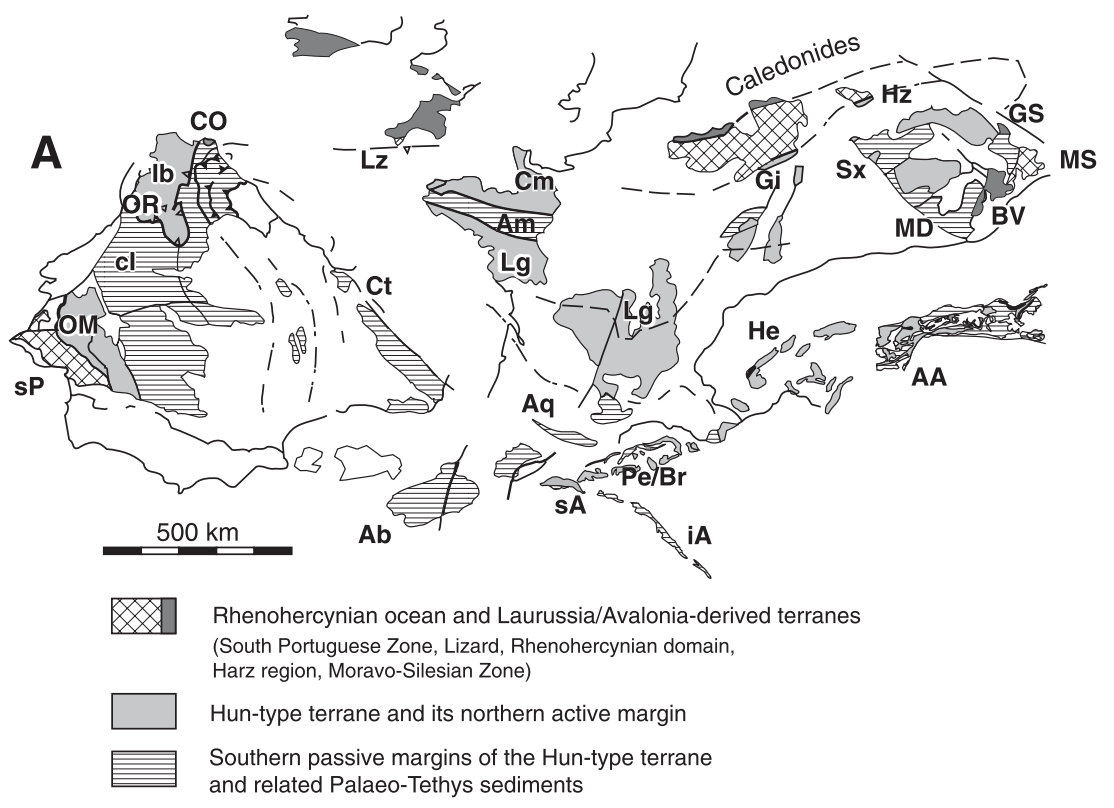

B
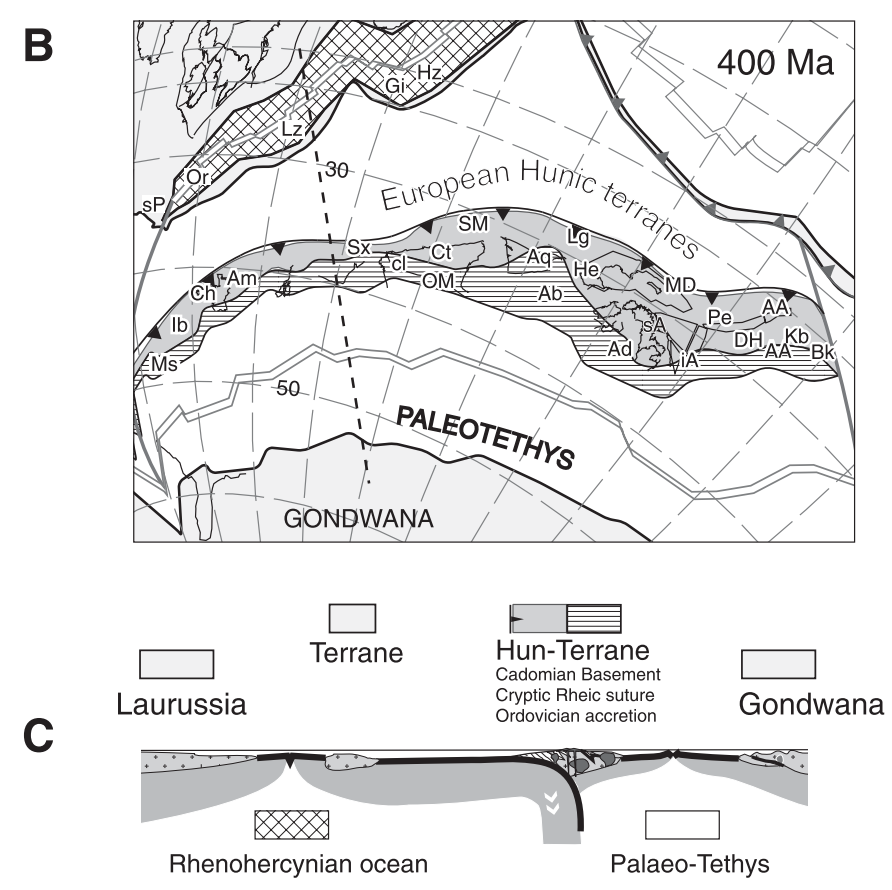
Silurian, accompanied by the opening of the PalaeoTethys (Fig. 4). Most of these future constituents of the Variscan orogen in Central Europe were strongly overprinted during Variscan and/or Alpine events, and their nomenclature is largely dominated by their belonging to Variscan (e.g. Kossmat, 1927), resp. Alpine (Alpine Realms) tectonostratigraphic units. Considering their pre-Variscan origin and evolution, we tentatively propose a terminology being the mirror of their Early Palaeozoic evolution (von Raumer et al., 2001; von Raumer et al., 2002).

We distinguished tectonostratigraphic units containing Cadomian basement, Neoproterozoic to Cambrian active margin settings, and Ordovician accretionary stages, which belong to the Hun superterrane, formerly situated at the eastern continuation of Avalonia along the Gondwanan border. These units represent the leading edge of the Hun superterrane and include a Middle Ordovician suture of an aborted Rheic ocean (Fig. 5). Units to the south of those are characterized by the opening of the Palaeo-Tethys, which separated the Hun superterrane from Gondwana in Late Silurian times.

This distribution was transformed during the Variscan orogeny with the addition of elements derived from Laurussia resp. Avalonia. This is the case for the classical Rhenohercynian zone, together with the Lizard, the South Portuguese and the Moravo-Silesian Zones (Figs. 3 and 5). They represent a Devonian oceanic domain opened within the Laurussian southern margin, due to a Gondwana-directed slab pull. The leading edge of the Hun superterrane is represented at that time by a Silurian-Devonian active margin (the mid-German Crystalline Rise).

We thus obtain the following main plate-tectonic units (Fig. 5):

- Terranes detached from either Laurentia-Baltica or Avalonia (e.g. BV, GS, Is, LM, Mo) and opening of the Rhenohercynian ocean (South Portuguese Zone, Lizard complex, Rhenohercynian domain, Moravo-Silesian region).

- Hun-type terranes and its northern active margin (Phyllite zone-Rheic accretionary prism, and the Harz-Giessen zone-Rhenohercynian accretionary prism).

- Southern passive margin of the Hun-type terranes and related Palaeo-Tethys sediments (e.g. Saxothuringian zone, Central-Armorican zone).
A similar distribution is repeated with the Ligerian-Moldanubian, Helvetic-Cetic and PenninicAustroAlpine (partly) units representing the leading active margin of the superterrane, then the NoricBosnian, Aquitaine-Cantabrian units represent the southern passive margin of the terrane (northern Palaeo-Tethys margin). Thus, it is obvious that major lateral translations and duplication of terranes took place during the Variscan orogeny, possibly in a model similar to the one proposed by Johnston (2001) for the Great Alaskan Terrane. Finally to the south of these duplicated terranes, we find (Fig. 5):

- Gondwana - the southern Palaeo-Tethys passive
margin.

After a geological history made of contrasting geodynamic stages since the Neoproterozoic/Cambrian, and going from an active margin setting to accretion of terranes and their duplication to ensialic rifting and continent-continent collision, the preVariscan building blocks, separated at different times from Gondwana, were reassembled during the Variscan orogeny. Part of them was strongly involved in the Alpine orogen. Consequently, collisional orogens do not just represent newly formed crust, but are mainly built up by large inherited continental blocks, including their lithospheric roots (e.g. Rampone and Piccardo, 2000). The Variscan cordillera stage contributed for a certain amount to crustal growth through large-scale granitic emplacement. This crustal material was preserved through Permo-Carboniferous widespread rifting. In contrast, the Alpine orogeny and the duplication of the lithosphere induced a loss of continental material through subduction/underplating and important erosion. We are aware that such comparative studies can only serve as a contribution for necessary further discussion.

\section{Acknowledgements}

We thank the leaders of IGCP 453 to have accepted the organization of the 2002 field meeting at Sion in western Switzerland. Our contribution profited from the careful reviews by St. Reddy (Perth) and F. Neubauer (Salzburg), and from remarks of an anonymous reviewer. Additionally, we thank G. Borel 
(Lausanne), J. Mosar (Fribourg) and A. Zeh (Würzburg) for their helpful suggestions.

\section{References}

Abati, J., et al., 1999. Early Ordovician orogenic event in Galicia (NW Spain): evidence from $\mathrm{U}-\mathrm{Pb}$ ages in the uppermost unit of the Ordenes Complex. Earth and Planetary Science Letters 165, $213-228$.

Barbey, P., Cheilletz, A., Laumonier, B., 2001. The Canigou orthogneisses (Eastern Pyrenees, France, Spain): an early Ordovician rapakivi granite laccolith and its contact aureole. Comptes Rendus de l'Academie des Sciences de Paris 332, 129-136.

Belka, Z., Valverde-Vaquero, P., Dörr, W., Ahrendt, H., Wemmer, K., Franke, W., Schäfer, H.J., 2002. Accretion of first Gondwana-derived terranes at the margin of Baltica. In: Winchester, J.A., Verniers, J., Pharaoh, T.C. (Eds.), Geological Society of London, Special Publications, vol. 201, pp. 19-36.

Bertrand, J.M., et al., 2000. SHRIMP and IDTIMS U-Pb zircon ages of the pre-Alpine basement in the Internal Western Alps (Savoy and Piemont). Schweizerische Mineralogische und Petrographische Mitteilungen 80, 225-248.

Böhm, C.O., 1996. Provenance and pre-Mesozoic evolution of the Lucomagno unit (Central Swiss Alps): a geochemical, isotopic and geochronological approach. Unpubl. Dr. Thesis. ETH Zürich.

Boriani, A., Giobbi Origoni, E., Del Moro, A., 1981. Composition, level of intrusion and age of the "Serie dei Laghi" orthogneisses (Northern Italy-Ticino, Switzerland). Rendiconti della Società Italiana di Mineralogia e Petrologia 38, 191-205.

Briand, B., Bouchardon, J.L., Ouali, H., Piboule, M., Capiez, P., 1995. Geochemistry of bimodal amphibolitic-felsic gneiss complexes from eastern Massif Central, France. Geological Magazine 132, 321-337.

Burg, J.P., van den Driessche, J., Brun, J.P., 1994. Syn- to postthickening extension in the Variscan belt of Western Europe. Modes and structural consequences. Géologie de la France 3, $33-51$.

Bussy, F., von Raumer, J., 1994. U-Pb geochronology of Palaeozoic magmatic events in the Mont-Blanc Crystalline Massif, Western Alps. Schweizerische Mineralogische und Petrographische Mitteilungen 74, 514-515.

Bussy, F., Derron, M.H., Jaquod, J., Sartori, M., Thélin, P., 1996. The 500 Ma-old Thyon metagranite: a new A-type granite occurrence in the Western Penninic Alps (Wallis, Switzerland). European Journal of Mineralogy 8, 565-575.

Bussy, F., Hernandez, J., von Raumer, J., 2000. Bimodal magmatism as a consequence of the post-collisional readjustment of the thickened variscan continental lithosphere (Aiguilles Rouges/ Mont-Blanc Massifs, Western Alps). Transactions of the Royal Society of Edinburgh. Earth Sciences 91 (1-2), 221-233.

Bussy, F., von Raumer, J.F., Capuzzo, N., 2001. Mont BlancAiguilles Rouges Massifs-(External Massifs). Field-Trip 1. Mémoires de Géologie, Lausanne 36, 53-85.

Capuzzo, N., Bussy, F., 2000. High-precision dating and origin of synsedimentary volcanism in the Late Carboniferous Salvan-
Dorénaz basin (Aiguilles-Rouges Massif, Western Alps). Schweizerische Mineralogische und Petrographische Mitteilungen 80, 147-167.

Chen, F., Hegner, E., Todt, W., 2000. Zircon ages and Nd Isotopic and chemical compositions of orthogneisses from the Black Forest, Germany: evidence for a Cambrian magmatic arc. International Journal of Earth Sciences 88, 791-802.

Crowley, Q.G., Floyd, P.A., Winchester, J.A., Franke, W., Holland, J.G., 2000. Early Palaeozoic rift-related magmatism in Variscan Europe: fragmentation of the Armorican Terrane Assemblage. Terra Nova 12, 171-180.

Debon, F., Guerrot, C., Ménot, R.P., Vivier, G., Cocherie, A., 1998. Late Variscan granites of the Belledonne massif (French Alps) a lower Visean magnesian plutonism. Schweizerische Mineralogische und Petrographische Mitteilungen 78, 67-85.

Escher, A., et al., 1996. Geologic framework and structural evolution of the Western Swiss Alps. In: Pfiffner, O.A., Lehner, P., Heitzmann, P., Müller, S., Steck, A. (Eds.), Deep Structure of Switzerland. Results from the National Research Program 20 (NRP20). Birkhäuser, Basel, pp. 205-221.

Fernández-Suárez, J., Gutíerrez-Alonso, G., Jenner, G.A., Tubrett, M.N., 2000. New ideas on the Proterozoic-Early Palaeozoic evolution of NW Iberia: insights from $\mathrm{U}-\mathrm{Pb}$ detrital zircon ages. Precambrian Research 102, 185-206.

Finger, F., Hanzl, P., Pin, C., von Quadt, A., Steyrer, H.P., 2000. The Brunovistulian: Avalonian Precambrian sequence at the eastern end of the Central European Variscides? In: Franke, W., Haak, V., Oncken, O., Tanner, D. (Eds.), Orogenic processes-quantification and modelling in the Variscan belt of Central Europe. Geological Society, London Special Publications, London, vol. 179, pp. 103-112.

Floyd, P.A., Winchester, J., Seston, R., Kryza, R., Crowley, Q.G., 2000. Review of geochemical variation in Lower Palaeozoic metabasites from the NE Bohemian Massif: intracratonic rifting and plume-ridge interaction. In: Franke, W., Altherr, R., Haak, V., Oncken, O., Tanner, D. (Eds.), Orogenic processes - quantification and modelling in the Variscan belt of Central Europe. Geological Society of London, Special Publications, vol. 179, pp. $155-174$.

Franke, W., 1989. Tectonostratigraphic units in the Variscan belt of central Europe. Geological Society of America, Special Paper 290, 67-89.

Franke, W., Haak, V., Oncken, O., Tanner, D. (Eds.), 2000. Orogenic Processes-Quantification and Modelling in the Variscan Belt of Central Europe. Geological Society, London Special Publications, vol. 179. 459 pp.

Frey, M., Desmons, J., Neubauer, F. (Eds.), 1999. The new Metamorphic map of the Alps. Schweizerische Mineralogische und Petrographische Mitteilungen, vol. 79/1. Stäubli Verlag, Zürich. $230 \mathrm{pp}$.

Friedl, G., Finger, F., McNaughton, N.J., Fletcher, I.R., 2000. Deducing the ancestry of terranes: SHRIMP evidence for South America-derived Gondwana fragments in central Europe. Geology $28,1035-1038$.

Friedl, G., et al., 2002. U-Pb SHRIMP dating on multiple zoned zircons from a south-Bohemian granulite. Erlanger Geologische Abhandlungen, Sonderband 3, 28. 
Furnes, H., Kryza, R., Muszynski, A., Pin, C., Garmann, L.B., 1994. Geochemical evidence for progressive, rift-related early Palaeozoic volcanism in the western Sudetes. Journal of the Geological Society (London) 151, 91-109.

Giorgis, D., Thélin, P., Stampfli, G., Bussy, F., 1999. The MontMort metapelites: variscan metamorphism and geodynamic context (Briançonnais basement, Western Alps, Switzerland). Schweizerische Mineralogische und Petrographische Mitteilungen $79,381-398$.

Guillot, F., Liégois, J.P., Fabre, J., 1991. Des granophyres du Cambrien terminal dans le Mont Pourri (Vanoise, zonebriançonnaise: premièredatation $\mathrm{U}-\mathrm{Pb}$ sur zircon d'un socle des zones internes des Alpes françaises. Comptes Rendus de l'Académie des Sciences de Paris 313, 239-244.

Hatcher, R.D., 1983. Basement massifs in the Appalachians: their role in deformation during the Appalachian orogenies. Geological Journal 18, 255-265.

Haydoutov, I., 1989. Precambrian ophiolites, Cambrian island arc, and Variscan suture in the South Carpathian-Balkan region. Geology 17, 905-908.

Hegner, E., Kröner, A., 2000. Review of $\mathrm{Nd}$ isotopic data and xenocrystic and detrital zircon ages from the pre-Variscan basement in the eastern Bohemian Massif-speculation on palinspastic reconstructions. In: Franke, W., Haak, V., Oncken, O., Tanner, D. (Eds.), Orogenic Processes-quantification and Modelling in the Variscan Belt of Central Europe. Geological Society, London Special Publications, London, vol. 179, pp. 113-129.

Hoffman, P.F., 1991. Did the breakout of Laurentia turn Gondwanaland inside-out? Science 252, 1409-1412.

Johnston, S.T., 2001. The Great Alaskan Terrane wreck: reconciliation of paleomagnetic and geological data in the northern Cordillera. Earth and Planetary Science Letters 193, 259-272.

Kemnitz, H., Romer, R., Oncken, O., 2002. Gondwana break-up and the northern margin of the Saxothuringian belt (Variscides of Central Europe). International Journal of Earth Sciences 91, 246-259.

Keppie, J.D., Dostal, J., 1998. Birth of Avalon arc in Nova Scotia, Canada: geochemical evidence for 700-630 Ma back-arc rift volcanism of Gondwana. Geological Magazine $135,171-181$.

Kossmat, F., 1927. Gliederung des varistischen Gebirgsbaues. Abhandlungen der Saechsischen Geologischen Landes Anstalt 1, $1-39$.

Kröner, A., Hegner, E., 1998. Geochemistry, single zircon ages and $\mathrm{Sm}-\mathrm{Nd}$ systematics of granitoid rocks from the GorySowie (Owl Mts), Polish West Sudetes: evidence for Early Palaeozoic are-related plutonism. Journal of the Geological Society (London) $155,711-724$.

Kröner, A., Stipská, P., Schulmann, K., Jaeckel, P., 2000. Chronological constraints on the pre-Variscan evolution of the northeastern margin of the Bohemian Massif, Czech Republik. In: Franke, W., Haak, V., Oncken, O., Tanner, D. (Eds.), Orogenic Processes-Quantification and Modelling in the Variscan Belt of Central Europe. Geological Society, London Special Publications, London, vol. 179, pp. 175-197.

Liebetrau, V., Nägler, T., 1994. Geochronologische und geoche- mische Diskussion der sogenannten "flüealgranitischen Assoziation" des Silvrettakristallins (Graubünden/Schweiz). Schweizerische Mineralogische Petrographische Mitteilungen $74,265-268$.

Liew, T.C., Hofmann, A.W., 1988. Precambrian crustal components, plutonic associations, plate environment of the Hercynian fold belt of Central Europe: indications from a $\mathrm{Nd}$ and $\mathrm{Sr}$ isotopic study. Contributions of Mineralogy and Petrology 98, $129-138$.

Linnemann, U., Gehmlich, M., Tichomirova, M., Buschmann, B., Bombach, K., 1998. Tectonostratigraphic events of the PeriGondwanan basement of the Saxo-Thuringian composite terrane (Central European Variscides). Schriften des Staatlichen Museums für Mineralogie und Geologie Dresden 9, 159-161.

Maniar, P.D., Piccoli, P.M., 1989. Tectonic discrimination of granitoids. Bulletin of the Geological Society of America 101, 635-643.

Martínez-Catalán, J.R., 1990. A non-cylindrical model for the northwest Iberian allochthonous terranes and their equivalents in the Hercynian belt of Western Europe. Tectonophysics 179, $253-272$.

Matte, P., 1986. Tectonics and plate tectonics model for the Variscan belt of Europe. Tectonophysics 126, 329-374.

Ménot, R.P., 1987. Magmatismes paléozoiques et structuration carbonifere du Massif de Belledonne (Alpes Françaises). Mém. et Doc. Centre Armoricain Etudes Structurales des Socles, Rennes, vol. 21, p. 465.

Müller, B., Klötzli, U., Schaltegger, U., Flisch, M., 1996. Early Cambrian oceanic plagiogranite in the Silvretta nappe eastern Alps: geochemical, zircon $\mathrm{U}-\mathrm{Pb}$ and $\mathrm{Rb}-\mathrm{Sr}$ data from garnethornblende-plagioclase gneisses. Geologische Rundschau 85, $822-831$.

Murphy, J.B., Nance, R.D., 1989. Model for the evolution of the Avalonian-Cadomian belt. Geology 17, 735-738.

Murphy, J.B., Keppie, J.D., Dostal, J., Nance, R., 1999. Neoproterozoic-early Paleozoic evolution of Avalonia. Geological Society of America, Special Paper 336, 253-266.

Nance, R., Murphy, J.B., 1994. Contrasting basement isotopic signatures and the palinspastic restoration of periphal orogens: example from the Neoproterozoic Avalonian-Cadomian belt. Geology 22, 617-620.

Nance, R.D., Murphy, J.B., 1996. Basement isotopic signatures and Neoproterozoic palaeogeography of Avalonian-Cadomian and related terranes in the circum-North Atlantic. In: Nance, R.D., Thompson, M.D. (Eds.), Avalonian and Related Peri-Gondwanan Terranes of the Circum-North Atlantic. Geological Society of America, Special Papers, vol. 304, pp. 333-346.

Neubauer, F., Frisch, W., 1993. The Austro-Alpine metamorphic basement east of the Tauern window. In: von Raumer, J., Neubauer, F. (Eds.), The Pre-Mesozoic Geology in the Alps. Springer, Heidelberg, pp. 515-536.

Niggli, E., 1960. Mineralzonen der alpinen Metamorphose in den Alpen, 21. International Geological Congress, Kopenhagen 13, $132-138$.

Oberli, F., Meier, M., Biino, G., 1994. Time constraints on the preVariscan magmatic/metamorphic evolution of the Gotthard and Tavetsch units derived from single-zircon $\mathrm{U}-\mathrm{Pb}$ results. Schwei- 
zerische Mineralogische und Petrographische Mitteilungen 74, 483-488.

Oncken, O., 1997. Transformation of a magmatic arc and an orogenic root during oblique collision and it's consequences for the evolution of the European Variscides (Mid-German Crystalline rise). Geologische Rundschau 86, 2-20.

Paquette, L., Ménot, R.P., Peucat, J.J., 1989. REE, Sm-Nd and U$\mathrm{Pb}$ zircon study of eclogites from the Alpine External massifs (Western Alps): Evidence for crustal contamination. Earth and Planetary Science Letters 96, 181-198.

Pezotta, F., Pinarelli, L., 1994. The magmatic evolution of Ordovician metagranitoids of the Serie dei Laghi (Southern Alps): inferences from the petrological, geochemical, and $\mathrm{Sr}$ and $\mathrm{Nd}$ isotope data. Periodico di Mineralogia 63, 127-147.

Pfiffner, O.A., Lehner, P., Heitzmann, P., Müller, S., Steck, A. (Eds.), 1996. Deep Structure of Switzerland. Results from the National Research Program, vol. 20. Birkhäuser, Basel.

Pharaoh, T.J., 1999. Palaeozoic terranes and their lithospheric boundaries within the Trans-European Suture Zone (TESZ): a review. Tectonophysics $314,17-41$.

Pin, C., Marini, F., 1993. Early Ordovician continental break-up in Variscan Europe: $\mathrm{Nd}-\mathrm{Sr}$ isotope and trace element evidence from bimodal igneous associations of the Southern Massif central, France. Lithos 29, 177-196.

Pin, C., Ortega-Cuesta, L.A., Gil Ibarguchi, J.I., 1992. Mantle-derived, early Palaeozoic A-type metagranitoids from the NW Iberian massif: Nd isotope and trace element constraints. Bulletin de la Société Géologique de France 163, 483-494.

Poller, U., 1997. U-Pb single zircon study of gabbroic and granitoid rocks of Val Barlas-ch (Silvretta nappe, Switzerland). Schweizerische Mineralogische und Petrographische Mitteilungen $77,351-359$.

Poller, U., Nägler, T.F., Liebetrau, V., Galetti, G., 1997. The Mönchalpgneiss - geochemical characteristics and $\mathrm{Sm}-\mathrm{Nd}$ data of a polymetamorphic S-type granitoid (Silvretta nappe/Switzerland). European Journal of Mineralogy 9, 411-422.

Rampone, E., Piccardo, G., 2000. The ophiolite-oceanic lithosphere analogue: new insights from the northern Apennines (Italy). In: Dilek, Y., Moores, E.M., Elthon, D., Nicolas, A. (Eds.), Ophiolites and Oceanic Crust: New Insights from Field Studies and the Ocean Drilling Project. Geological Society of America, Special Paper, vol. 349, pp. 21-34.

Ribeiro, A., Sanderson, D., 1996. SW-Iberia-transpressional orogeny in the Variscides. In: Gee, D.G., Zeyen, H.J. (Eds.), EUROPROBE 1996 Lithosphere Dynamics. Origin and Evolution of Continents. EUROPROBE Secretariate Uppsala University, Uppsala, pp. 91-94.

Schaltegger, U., Gebauer, D., 1999. Pre-Alpine geochronology of the Central, Western and Southern Alps. Schweizerische Mineralogische und Petrographische Mitteilungen 79, 79-87.

Schaltegger, U., et al., 1997. A Cambrian island arc in the Silvretta nappe: constraints from geochemistry and geochronology. Schweizerische Mineralogische und Petrographische Mitteilungen $77,337-350$.

Schindlmayr, A., 1999. Granitoids and plutonic evolution of the Ötztal-Stubai Massif. Unpubl. Dr. Thesis. Universität Salzburg. $287 \mathrm{pp}$.
Sengör, A.M.C., 1985. East Asian tectonic collage. Nature 318, $16-17$.

Stampfli, G., 1993. Le Briançonnais, terrain exotique dans les Alpes? Eclogae Geologicae Helvetiae 86, 1-45.

Stampfli, G.M., 2000. Tethyan oceans. In: Bozkurt, E., Winchester, J.A., Piper, I.D.A. (Eds.), Tectonics and Magmatism in Turkey and the Surrounding Area. Geological Society, London Special Publications, London, vol. 173, pp. 1-23.

Stampfli, G. (Ed.), 2001. Geology of the Western Swiss Alps, A Guide-book. Mémoires de Géologie (Lausanne), vol. 36. 195 pp.

Stampfli, G.M., Borel, G.D., 2002. A plate tectonic model for the Paleozoic and Mesozoic constrained by dynamic plate boundaries and restored synthetic oceanic isochrons. Earth and Planetary Science Letters 196, 17-33.

Stampfli, G.M., et al., 1998. Subduction and obduction processes in the Western Alps. Tectonophysics 296, 159-204.

Stampfli, G.M., Borel, G., Cavazza, W., Mosar, J., Ziegler, P.A., 2001a. The paleotectonic atlas of the PeriTethyan domain. CDROM, European Geophysical Society.

Stampfli, G.M., von Raumer, J., Borel, G., Bussy, F., 2001b. The Variscan and pre-Variscan evolution. In: Stampfli, G.M. (Ed.), Geology of the Western Swiss Alps, A Guide-book. Mémoires de Géologie (Lausanne), vol. 36, pp. 28-41.

Stampfli, G.M., von Raumer, J., Borel, G., 2002. The Paleozoic evolution of pre-Variscan terranes: from Gondwana to the Variscan collision. Geological Society of America, Special Paper 364, $263-280$.

Steck, A., Epard, J.L., Escher, A., Gouffon, Y., Masson, H. (Eds.), 2001. Carte Tectonique des Alpes de Suisse Occidentale. Note Explicative, Carte Géologique Spéciale, vol. 123. Office Fédéral des Eaux et de la Géologie, Bern.

Stipska, P., Schulmann, K., Thompson, A.B., Jezek, J., Kröner, A., 2001. Thermo-mechanical role of a Cambro-Ordovician palaeorift during the Variscan collision: the NE margin of the Bohemian Massif. Tectonophysics 332, 239-253.

Storey, B.C., 1995. The role of mantle plumes in continental breakup: case histories from Gondwanaland. Nature 377, 301-308.

Thélin, P., Sartori, M., Burri, M., Gouffon, Y., Chessex, R., 1993. The pre-Alpine basement of the Briançonnais (Wallis, Switzerland). In: von Raumer, J., Neubauer, F. (Eds.), The Pre-Mesozoic Geology in the Alps. Springer, Heidelberg, pp. 297-315.

Torsvik, T.H., 1998. Palaeozoic palaeogeography: a North Atlantic viewpoint. Geologiska Föreningens i Stockholm Förhandlingar 120, 109-118.

Torsvik, T.H., Smethurst, M.A., 1999. Plate tectonic modeling: virtual reality with GMAP. Computers and Geosciences 25, $395-402$.

Ugidos, J.M., et al., 1997. Provenance of Upper PrecambrianLower Cambrian shales in the Central Iberian Zone, Spain: evidence from a chemical and isotopic study. Chemical Geology $136,55-70$.

Valverde-Vaquero, P., et al., 2000. U-Pb single-grain dating of detrital zircon in the Cambrian of Central Poland: implications for Gondwana versus Baltica provenance studies. Earth and Planetary Science Letters 184, 225-240. 
Van der Voo, R., 1993. Paleomagnetism of the Atlantic, Tethys and Iapetus Oceans. Cambridge Univ. Press, Cambridge. 411 pp.

Van Staal, C.R., Dewey, J.F., Niocaill, C.M., Mckerrow, W.S., 1998. The Cambrian-Silurian tectonic evolution of the Northern Appalachians and British Caledonides: history of a complex, west and southwest Pacific-type segment of Iapetus. In: Blundell, D.J., Scott, A.C. (Eds.), Lyell: The Past is the Key to the Present. Geological Society, London Special Publications, London, pp. 199-242.

Vavassis, I., De Bono, I.A., Stampfli, G.M., Giorgis, D., Valloton, A., Amelin, Y., 2000. U-Pb and Ar-Ar geochronological data from the Pelagonian basement in Evia (Greece): geodynamic implications for the evolution of Paleotethys. Schweizerische Mineralogische und Petrographische Mitteilungen 80, 21-43.

Voll, G., 1976. The crystallization of quartz, biotite, and feldspar from Erstfeld to the Bernhard Nappe, Swiss Alps, and its geological significance. Schweizerische Mineralogische und Petrographische Mitteilungen 56, 641-647.

von Quadt, A., 1992. U-Pb zircon and Sm-Nd geochronology of mafic and ultramafic rocks from the central part of the Tauern Window (Eastern Alps). Contributions of Mineralogy and Petrology $110,57-67$.

von Raumer, J.F., 1967. Kristallisation und Gefègebildung im Mont-Blanc-Granit. Schweizerische Mineralogische und Petrographische Mitteilungen 47, 499-579.

von Raumer, J.F., 1984. The external massifs, relics of variscan basement in the Alps. Geologische Rundschau 73, 1-31.

von Raumer, J.F., 1998. The Palaeozoic evolution in the Alpsfrom Gondwana to Pangea. Geologische Rundschau 87, 407-435.

von Raumer, J.F., Neubauer, F. (Eds.), 1993. The Pre-Mesozoic Geology in the Alps. Springer, Heidelberg. 677 pp.

von Raumer, J.F., Neubauer, F., 1994. The Palaeozoic evolution of the Alps. Schweizerische Mineralogische und Petrographische Mitteilungen 74, 459-467. von Raumer, J.F., et al., 1999a. The Palaeozoic metamorphic evolution of the Alpine External Massifs. Schweizerische Mineralogische und Petrographische Mitteilungen 79, 5-22.

von Raumer, J.F., Bussy, F., Schaltegger, U., 1999b. Ordovician granitoids in the Alps: significance and Peri-Gondwanan correlation. Schriften der Alfred-Wegener-Stiftung, Terra Nostra 99/1, 165.

von Raumer, J.F., Stampfli, G.M., Borel, G., 2001. Plate tectonic nomenclature for pre-Variscan units in Central Europe: a discussion. Journal of Conference Abstracts 6 (1), 632.

von Raumer, J.F., Stampfli, G.M., Borel, G., Bussy, F., 2002. The organization of pre-Variscan basement areas at the northGondwanan margin. International Journal of Earth Sciences $91,35-52$.

Wingate, M.T.D., Pisarevski, S.A., Evans, D.A.D., 2002. Rodinia connections between Australia and Laurentia: no SWEAT, no AUSWUS? Terra Nova 14, 121-128.

Wirsing, A., 1997. Die Orthogneise des oberen Val Bérard (Aiguilles-Rouges-Massiv, Westalpen, Frankreich). Unpubl. Dr. Thesis. Fribourg University. $141 \mathrm{pp}$.

Zeh, A., Brätz, H., Millar, I.L., Williams, I.S., 2001. A combined zircon SHRIMP and $\mathrm{Sm}-\mathrm{Nd}$ isotope study of high-grade paragneisses from the Mid-German Crystalline Rise: evidence for northern Gondwana and Grenvillian provenance. Journal of the Geological Society (London) 158, 983-994.

Ziegler, P.A., Cloething, S., Guiraud, R., Stampfli, G.M., 2001. Peri-Tethyan platforms: constraints on dynamics of rifting and basin inversion. In: Ziegler, P.A., Cavazza, W., Robertson, S., Crasquin-Soleau, S. (Eds.), Peri Tethys Memoir, vol. 6. Mémoires du Muséum National d'Histoire Naturelle, Paris, pp. $9-49$.

Zulauf, G., et al., 1999. Age constraints on the Cadomian evolution of the Teplá Barrandian unit (Bohemian Massif) through electron microprobe dating of metamorphic monazite. Zeitschrift der Deutschen Geologischen Gesellschaft 150, 627-639. 